Dhaka Univ. J. Sci. 61(2): 199-201, 2013 (July)

\title{
Chemical Composition of Some Leafy Vegetables of Bangladesh
}

\author{
Kamal Karmakar, Tanvir Muslim* and Md. Azizur Rahman
}

Department of Chemistry, Dhaka University, Dhaka-1000, Bangladesh

(Received : 20 November 2012; Accepted : 10 February 2013)

\begin{abstract}
The chemical composition, such as water, ash, iron and total vitamin C content, of 28 green leafy vegetables were analyzed in this investigation. The water content of the leafy vegetables varied between 83.8 to $95.5 \mathrm{~g} / 100 \mathrm{~g}$ fresh vegetable sample. The ash content of the samples varied between 8.0 to $22.6 \mathrm{~g} / 100 \mathrm{~g}$ of dry vegetable powder. The iron content of the leafy vegetables varied from 11.8 to 78.2 $\mathrm{mg} / 100 \mathrm{~g}$ of dry sample and the total vitamin C content varied from 191.5 to $21.6 \mathrm{mg} / 100 \mathrm{~g}$ of fresh sample. These findings conclusively suggest that the locally available leafy vegetables are good source of water, minerals, iron and vitamin C.
\end{abstract}

Keywords: Leafy vegetables, composition, water, ash, iron, total vitamin C, Bangladesh.

\section{Introduction}

Vegetables play a vital role in our daily food list and these are important sources of nutrients. People can survive on vegetables alone if they have nothing else to eat. This is specifically true for the poor people of the village of Bangladesh. The importance of vegetables is unlimited because the required elements which are essential for our body are obtained from vegetables. More specifically green leafy vegetables have the greatest impact on blood $\mathrm{pH}$, offsetting the acidity caused by a number of unavoidable factors. In addition to the nutritional value and its possible effects of the blood $\mathrm{pH}$, these vegetables can detoxify the unwanted metals and impurities of our body, found in modern highly processed diet. Leafy vegetables play a leading role among various kinds of food in dietary intake to keep our body fit and healthy. For this, its thorough investigation is necessary to find out the different nutritional aspects of the leafy vegetables, which are commonly consumed by the people of Bangladesh. Although investigations on the leafy vegetables have been carried out ${ }^{1-2}$ more investigations are necessary using the modern techniques to explore their latent importance as nutritional aspects and medicinal role. With this end in view, this project was undertaken to carry out a thorough analysis of some indigenous leafy vegetables.

The present report deals with the nutritional status of lesserknown underutilized leafy vegetables grown in Bangladesh and hence to explore its importance as a diet for local people.

Table 1. English, local and Botanical names of the collected leafy vegetables of Bangladesh

\begin{tabular}{|c|c|c|c|c|}
\hline $\begin{array}{l}\text { Sl. } \\
\text { No. }\end{array}$ & English Name & Local Name & Botanical Name & Family \\
\hline 1 & Turnip leaves & Shalgom Pata & Brassica rapa L. var. rapa & Brassicaceae \\
\hline 2 & Joseph’s coat leaves & Lal Shak & Amaranthus tricolor L. & Amaranthaceae \\
\hline 3 & Garden spinach leaves & Palong Shak & Spinacia oleracea L. & Amaranthaceae \\
\hline 4 & Coriander leaves & Dhoney Pata & Coriandrum sativum L. & Apiaceae \\
\hline 5 & Cauliflower leaves & Fulkopi Pata & B. oleracea L. var. botrytis & Brassicaceae \\
\hline 6 & Radish leaves & Mula Pata & Raphanus sativus L. & $\overline{\text { Brassicaceae }}$ \\
\hline 7 & Onion leaves & Pyaz Pata & Allium cepa $\mathrm{L}$. & Amaryllidaceae \\
\hline 8 & Bottle gourd leaves & Lau Shak & Lagenaria siceraria (Molina) Standl. & Cucurbitaceae \\
\hline 9 & Sweet potato leaves & Mishti Alu Shak & Ipomoea batatas L. & Convolvualceae \\
\hline 10 & Marsh Herb leaves & Helencha Shak & Enhydra fluctuans Lour. & Compositae \\
\hline 11 & Water spinach leaves & Kalmi Shak & Ipomoea aquatica Forssk & Convolvulaceae \\
\hline 12 & Amaranths leaves & Data Shak & Amaranthus gangeticus L. & Amaranthaceae \\
\hline 13 & Jute leaves & Pat Shak & Corchorus capsularis L. & Malvaceae \\
\hline 14 & Indian spinach leaves & Pui Shak & Basella rubra L. & Basellaceae \\
\hline 15 & Mint leaves & Pudina Pata & Mentha viridis L. & Lamiaceae \\
\hline 16 & Garden lettuce leaves & Latus Pata & Lactuca sativa L. & Asteraceae \\
\hline 17 & Mustard leaves & Sarisha Shak & Brassica napus L. & Brassicaceae \\
\hline 18 & Pea leaves & Motor Shak & Pisum sativum L. & Fabaceae \\
\hline 19 & Indian pennywort leaves & Thankuni Pata & Centella asiatica L. & Apiaceae \\
\hline 20 & Fern leaves & Dhake Shak & Diplazium esculentum & Athyriaceae \\
\hline 21 & Chickling pea leaves & Kaloe Shak & Lathyrus sativus L. & Fabaceae \\
\hline 22 & Fenugreek leaves & Maythi Shak & Trigonella foenum-graecum L. & Fabaceae \\
\hline 23 & Goose foot leaves & Bathua Shak & Chenopodium album L. & Amaranthaceae \\
\hline 24 & Slender carpet weed leaves & Gima Shak & Glinus oppositifolius L. & Molluginaceae \\
\hline 25 & Sweet gourd leaves & Mistekumra Shak & Cucurbita maxima Duch. & Cucurbitaceae \\
\hline 26 & Ash gourd leaves & Chal kumra Shak & Benincasa hispida (Thunb.) Cogn. & Cucurbitaceae \\
\hline 27 & Taro leaves & Kachu Shak & Colocasia esculenta L. & Araceae \\
\hline 28 & Starthorn leaves & Sulmardon Shak & Hygrophila auriculata (Schum.) Heyne. & Acanthaceae \\
\hline
\end{tabular}

*Author for Correspondence, e-mail: tmuslim@gmail.com 


\section{Experimental}

\section{Sample collection}

The leafy vegetables (Table-1) were collected from different places such as from local market, paddy field, crop field or side of river of Dhaka, Gazipur and Barisal District. Each of the collected fresh vegetable samples was washed with water to remove mud and dust particles. The cleaned raw plant material was first dried at room temperature and then in an oven at $45^{\circ} \mathrm{C}$. The dried plant material was grinded to powder by a Cyclotec grinder (200 meshes) and the powder was stored in air tight bottle. The dried vegetable powder was used for estimation of ash and iron analysis. Total vitamin C and water content were determined using fresh vegetable sample. The taxonomy of the plants was confirmed in consultation with an expert in the Department of Botany,
University of Dhaka, Bangladesh. A voucher specimen of each plant was deposited in the Bangladesh National Herbarium (BNH).

\section{Determination of Different nutrients}

The water, ash, iron, and total vitamin $\mathrm{C}$ content of the leafy vegetables (Table-1) were determined following standard procedure $^{3-5}$. Each of the samples was collected from three different places and each parameter was determined in triplicate. The average value of three determinations was used in presenting result of each parameter for each sample. The values of water and total vitamin C content were expressed on fresh sample basis. The values of iron content and ash content were expressed on dry powder basis. The results are given in Table- 2 .

\section{Table 2. Composition of leafy vegetables}

\begin{tabular}{|c|c|c|c|c|c|}
\hline \multirow{2}{*}{$\begin{array}{c}\text { Serial } \\
\text { No. }\end{array}$} & \multirow[t]{2}{*}{ Name of the sample } & \multicolumn{4}{|c|}{ Results (mean \pm s.d.) } \\
\hline & & Water content* & Ash content** & $\begin{array}{c}\text { Ascorbic acid } \\
\text { content } \dagger\end{array}$ & Iron content $\neq$ \\
\hline 1 & Turnip leaves & $84.4 \pm 0.4$ & $10.25 \pm 0.1$ & $191.5 \pm 1.7$ & $15.79 \pm 0.2$ \\
\hline 2 & Joseph's coat leaves & $91.5 \pm 0.7$ & $17.00 \pm 0.1$ & $76.5 \pm 1.5$ & $55.11 \pm 0.9$ \\
\hline 3 & Garden spinach leaves & $95.5 \pm 0.2$ & $18.75 \pm 0.3$ & $41.2 \pm 1.4$ & $41.65 \pm 0.4$ \\
\hline 4 & Coriander leaves & $88.0 \pm 0.5$ & $20.25 \pm 0.3$ & $140.5 \pm 0.8$ & $41.18 \pm 1.2$ \\
\hline 5 & Cauliflower leaves & $92.9 \pm 0.6$ & $13.20 \pm 0.1$ & $165.6 \pm 1.0$ & $19.39 \pm 0.7$ \\
\hline 6 & Radish leaves & $93.5 \pm 0.3$ & $20.50 \pm 0.2$ & $139.5 \pm 0.5$ & $64.31 \pm 1.1$ \\
\hline 7 & Onion leaves & $89.6 \pm 1.1$ & $8.00 \pm 0.5$ & $29.0 \pm 1.0$ & $26.50 \pm 0.5$ \\
\hline 8 & Bottle gourd leaves & $92.8 \pm 0.8$ & $14.50 \pm 0.2$ & $89.0 \pm 1.0$ & $38.11 \pm 1.1$ \\
\hline 9 & Sweet potato leaves & $91.7 \pm 0.3$ & $12.00 \pm 1.0$ & $28.8 \pm 0.8$ & $32.84 \pm 0.8$ \\
\hline 10 & Marsh herb leaves & $91.6 \pm 0.4$ & $15.00 \pm 0.5$ & $30.1 \pm 0.7$ & $49.04 \pm 1.0$ \\
\hline 11 & Water spinach leaves & $92.6 \pm 0.5$ & $16.01 \pm 0.3$ & $36.4 \pm 0.9$ & $21.53 \pm 0.5$ \\
\hline 12 & Amaranths leaves & $90.0 \pm 0.8$ & $16.74 \pm 1.1$ & $42.2 \pm 0.7$ & $37.05 \pm 0.9$ \\
\hline 13 & Jute leaves & $83.8 \pm 0.7$ & $11.60 \pm 0.3$ & $107.2 \pm 1.0$ & $58.03 \pm 1.0$ \\
\hline 14 & Indian spinach leaves & $94.5 \pm 0.8$ & $16.28 \pm 0.2$ & $66.7 \pm 0.7$ & $44.57 \pm 0.5$ \\
\hline 15 & Mint leaves & $85.2 \pm 0.2$ & $11.83 \pm 0.4$ & $32.6 \pm 0.5$ & $61.12 \pm 1.0$ \\
\hline 16 & Garden lettuce leaves & $94.9 \pm 0.9$ & $11.26 \pm 0.3$ & $21.6 \pm 0.5$ & $46.52 \pm 0.5$ \\
\hline 17 & Mustard leaves & $92.1 \pm 0.9$ & $16.27 \pm 0.5$ & $35.5 \pm 0.5$ & $21.53 \pm 0.5$ \\
\hline 18 & Pea leaves & $87.7 \pm 0.6$ & $8.70 \pm 0.4$ & $38.0 \pm 1.0$ & $33.04 \pm 1.0$ \\
\hline 19 & Indian pennywort leaves & $87.5 \pm 0.4$ & $13.10 \pm 0.5$ & $42.9 \pm 0.9$ & $35.74 \pm 0.3$ \\
\hline 20 & Fern leaves & $91.2 \pm 1.0$ & $11.00 \pm 0.4$ & $27.8 \pm 0.7$ & $24.71 \pm 0.3$ \\
\hline 21 & Chickling pea leaves & $87.7 \pm 0.3$ & $11.22 \pm 0.6$ & $59.1 \pm 1.0$ & $42.76 \pm 0.8$ \\
\hline 22 & Fenugreek leaves & $86.5 \pm 1.2$ & $10.30 \pm 0.3$ & $94.8 \pm 1.1$ & $21.54 \pm 0.5$ \\
\hline 23 & Goose foot leaves & $84.3 \pm 0.6$ & $22.60 \pm 0.6$ & $36.0 \pm 0.5$ & $11.78 \pm 0.7$ \\
\hline 24 & Slender carpet weed leaves & $86.4 \pm 1.2$ & $16.37 \pm 0.2$ & $88.0 \pm 1.5$ & $78.24 \pm 0.8$ \\
\hline 25 & Sweet gourd leaves & $90.5 \pm 0.4$ & $14.60 \pm 0.4$ & $102.8 \pm 1.3$ & $36.05 \pm 0.9$ \\
\hline 26 & Ash gourd leaves & $91.5 \pm 0.2$ & $15.00 \pm 0.3$ & $79.2 \pm 1.2$ & $42.10 \pm 0.9$ \\
\hline 27 & Taro leaves & $91.9 \pm 0.9$ & $13.70 \pm 0.3$ & $69.6 \pm 0.5$ & $14.25 \pm 0.2$ \\
\hline 28 & Starthorn leaves & $90.5 \pm 0.5$ & $17.20 \pm 0.7$ & $39.7 \pm 1.7$ & $48.15 \pm 0.7$ \\
\hline
\end{tabular}

*g /100 g fresh vegetables; **g /100 g dry vegetable powder; †mg /100 g fresh vegetables; $¥ \mathrm{~g} / 100 \mathrm{~g}$ dry vegetable powder.

\section{Results and Discussion}

Twenty eight different leafy vegetables (Table-1) were collected locally and their moisture, ash, iron and total vitamin $\mathrm{C}$ content were determined ${ }^{3-5}$. Each parameter was determined for three different varieties of the same sample and each of the estimation was repeated for thrice. The average values are presented in Table-2.

It appears from the Table-2 that the water content varies from 83.8 to $95.5 \mathrm{~g} / 100 \mathrm{~g}$ in fresh samples. The water content of garden spinach leaves is found to be the highest (95.5 g/100 g) and lowest (83.8 g/100 g) in jute leaves. The water contents of the leaves of garden lettuce (94.9 g/100 g) and Indian spinach (94.5 g/100 g) are closer to the highest value. On the other hand the water contents of the leaves of radish (93.5 g/100 g), cauliflower (92.9 g/100 g), bottle gourd (92.8 g/100 g), water spinach (92.6 g/100 g), mustard (92.1 g/100 g), taro (91.9 g/100 g), sweet potato (91.7 g/100 g), marsh herb (91.6 g/100 g), Joseph's coat (91.5 g/100 g), ash gourd (91.5 g/100 g), fern (91.2 g/100 g), sweet gourd (90.5 g/100 g), starthorn (90.5 g/100 g) and amaranths (90.0 $\mathrm{g} / 100 \mathrm{~g})$, are very close. The water contents of other vegetables are a little bit higher than the lowest value. 
The ash content of goose foot leaves is found to be the highest (22.60 g/100 g) and lowest (8.0 g/100 g) in onion leaves. The ash contents of the leaves of radish (20.50 g/100 g), coriander (20.25 g/100 g), garden spinach (18.75 g/100 g), starthorn (17.20 g/100 g), Joseph's coat (17.00 g/100 g), amaranths (16.74 g/100 g), slender carpet weed (16.37 $\mathrm{g} / 100 \mathrm{~g})$, Indian spinach (16.28 g/100 g), mustard (16.27 $\mathrm{g} / 100 \mathrm{~g})$ and water spinach (16.01 g/100 g), are closer to the highest value but these are almost double or more than that of the lowest value. This indicates that the leafy vegetables contain different types of minerals which are very important for human.

The iron content of the samples was determined by formation of iron(II)-1,10-phenanthroline complex followed by measurement of the absorbance (at $510 \mathrm{~nm}$ ) of the sample solutions ${ }^{4}$. Comparing this absorbance with that of standard samples, the proportion of iron in the respective samples was estimated. The results show (Table -2) that the iron content of the leafy vegetables varies from 11.78 to $78.24 \mathrm{mg} / 100 \mathrm{~g}$ of dry vegetable powder sample. It is found to be the highest $(78.24 \mathrm{mg} / 100 \mathrm{~g})$ in slender carpet weed leaves and lowest $(11.78 \mathrm{mg} / 100 \mathrm{~g})$ in goose foot leaves. The iron contents of the leaves of radish, mint, jute and Joseph's coat are found to be 64.31, 61.12, 58.03 and 55.1 $\mathrm{mg} / 100 \mathrm{~g}$ of dry powder, respectively. The iron contents of the other vegetables are in between 12 and $49 \mathrm{mg} / 100 \mathrm{~g}$ of dry powder. These results indicate that the iron content in the leafy vegetable varies within wide range. This result provides an indication towards the utility of the leafy vegetables as a source of iron in our daily diet. The requirement of iron for an adult women and men are $18 \mathrm{mg}$ and $8 \mathrm{mg}$ per day ${ }^{6}$. It may be concluded from the results that about $50 \mathrm{~g}$ of the leafy vegetables may fulfill the requirement of our daily need.

The amount of total vitamin $\mathrm{C}$ is the highest $(191.5 \mathrm{mg} / 100$ g) in turnip leaves and the lowest (21.6 mg/100 g) in garden lettuce leaves. The amounts of total vitamin $\mathrm{C}$ in the leaves of cauliflower, coriander, radish, jute and in sweet gourd are found to be 165.6, 140.5, 139.5, 107.2 and $102.8 \mathrm{mg} / 100 \mathrm{~g}$ of fresh leaves, respectively. On the other hand total vitamin C contents in the leaves of Indian pennywort, amaranths, garden spinach, starthorn, pea, water spinach, goose foot, mustard, mint, marsh herb, onion, sweet potato and fern are estimated as 42.9, 42.2, 41.2, 39.7, 38.0, 36.4, 36.0, 35.5, 32.6, 30.1, 29.0, 28.8 and $27.8 \mathrm{mg} / 100 \mathrm{~g}$ of fresh leaves, respectively. The results indicate that total vitamin $\mathrm{C}$ content of the leafy vegetables varies widely and this information helps us to select these vegetables as a good source of vitamin $\mathrm{C}$ as diet in our daily food habit. Vitamin $\mathrm{C}$ is essential for the function of our immune system, as well as to repair our tissues and cells. Vitamin $\mathrm{C}$ also helps to protect our body from infection. Recommended requirement of vitamin $C$ is about $45 \mathrm{mg}$ per day for an adult ${ }^{6}$. About $100-150 \mathrm{~g}$ of leafy vegetables may fulfill our daily requirement of vitamin $C$.

From the present study, it is clear that the leafy vegetables are important source of minerals, iron and vitamin C. So, the poor people of the village of Bangladesh can survive on vegetables alone if they have nothing else to eat and this is generally found. Hence the findings, conclusively suggest that our local leafy vegetables are good source of nutrients as diet.

\section{Reference}

1. Mahbub, A., N. Jahan, T. Muslim and M. A. Rahman, 2010. Investigation of some constituents of two plants (Alternanthera philoxeroides and Alternanthera sessilis) of Amaranthaceae family. Dhaka Univ. J. Sci., 58(2), 327-328.

2. Islam, M. R., D. K. Paul and R. K. Shaha, 2004. Nutrational importance of some leafy vegetables available in Bangladesh. Pakistan J. Biol. Sci., 7(8), 1380-1383.

3. A.O.A.C., 1990. Official Methods of Analysis, 15th edition, Association of Official Analytical Chemists, Washington D.C., 739, 1250-1255.

4. Christian, G. D., 2004. Analytical Chemistry, 4th edition, John Wiley \& Sons, New York, 598-99.

5. Alam, M. A., T. Muslim and S. M. M. Rahman, 1998. Comparative study of total vitamin $\mathrm{C}$ in various fruits and vegetables of greater Sylhet area. Journal of Bangladesh Chemical Society, 11(1\&2), 15-21.

6. World Health Organization, Food and Agricultural Organization of the United Nations, 2004. Vitamin and mineral requirements in human nutrition, 2nd Edition, World Health Organization. 